\title{
LEACHING AND CARRYOVER FOR SAFRINHA CORN OF THE HERBICIDES IMAZAPYR + IMAZAPIC IN SOIL UNDER DIFFERENT WATER CONDITIONS ${ }^{1}$
}

\author{
AMANDA DOS SANTOS SOUZA ${ }^{2}$, JÉSSICA FERREIRA LOURENÇO LEAL ${ }^{2}$, ANA CLAUDIA LANGARO $^{2 *}$, \\ GLEDSON SOARES DE CARVALHO ${ }^{2}$, CAMILA FERREIRA DE PINHO ${ }^{2}$
}

\begin{abstract}
Soil moisture can alter the transport and permanence of pre-emergent herbicides. The objective of this work was to evaluate the influence of water availability in the soil on the leaching of a commercial mixture of the herbicides imazapyr + imazapic, as well as the carryover effect of this herbicide in corn planted in succession to soybean. The experiment was carried out in leaching columns in a randomized block design with 4 replications. A $3 \times 3 \times 2$ factorial scheme was used, with factor A being the irrigation $(130 \%, 100 \%$ and $70 \%$ of field capacity (CC)), factor B the doses of the commercial mixture of the herbicides imazapyr + imazapic $\left(0.00+0.00 ; 52.5+17.5\right.$ and $\left.105+35 \mathrm{~g} \mathrm{ha}^{-1}\right)$ and factor $\mathrm{C}$ at soil depth $(0-0.3 \mathrm{~m}$ and $0.3-0.6 \mathrm{~m})$. Soybean sowing was performed at the top of the columns and immediately after herbicide mixture was applied. After 120 days the columns were opened, generating two sections, where corn (Zea mays) and the other watermelon (Citrullus lanatus) were sown as a bioindicator of herbicide residue. The fluorescence parameters of chlorophyll $a$ at 15 and 30 days after germination (DAG) and shoot dry matter accumulation at 30 DAG were evaluated. There was greater retention of the herbicide imazapyr + imazapic at a depth of $0-0.3 \mathrm{~m}$ at $70 \%$ $\mathrm{CC}$ condition and leaching at a depth of $0.3-0.6 \mathrm{~m}$ at $130 \% \mathrm{CC}$ condition, with a reduction in the mass accumulation of watermelon plants. The herbicide has a carryover potential for corn cultivation in soils maintained at $70 \% \mathrm{CC}$.
\end{abstract}

Keywords: Cultivation in succession. Imidazolinones. Persistence. Residual.

\section{LIXIVIAÇÃO E CARRYOVER PARA MILHO SAFRINHA DOS HERBICIDAS IMAZAPYR+IMAZAPIC EM SOLO SOB DIFERENTES CONDIÇÕES HÍDRICAS}

\begin{abstract}
RESUMO - A umidade do solo pode alterar o transporte e a permanência de herbicidas pré-emergentes. O objetivo deste trabalho foi avaliar a influência da disponibilidade de água no solo na lixiviação da mistura comercial dos herbicidas imazapyr+imazapic, bem como o efeito carryover deste herbicida no milho semeado em sucessão à soja. $\mathrm{O}$ experimento foi desenvolvido em colunas de lixiviação em delineamento de blocos ao acaso com 4 repetições. Foi utilizado esquema fatorial $3 \times 3 \times 2$, sendo o fator A as lâminas de irrigação (130\%, $100 \%$ e $70 \%$ da capacidade de campo (CC)), o fator B as doses da mistura comercial dos herbicidas imazapyr + imazapic $\left(0,00+0,00 ; 52,5+17,5\right.$ e $\left.105+35 \mathrm{~g} \mathrm{ha}^{-1}\right)$ e o fator $\mathrm{C}$ a profundidade $(0-0,3 \mathrm{~m} \mathrm{e} 0,3-0,6 \mathrm{~m})$. A semeadura da soja foi realizada no topo das colunas e imediatamente após foi realizada a aplicação da mistura dos herbicidas. Após 120 dias as colunas foram abertas, gerando duas canaletas, onde em uma foi semeado o milho (Zea mays) e na outra melancia (Citrullus lanatus) como bioindicadora do resíduo dos herbicidas. Foram avaliados os parâmetros fluorescência da clorofila $a$ aos 15 e 30 dias após germinação (DAG) e acúmulo de matéria seca de parte aérea aos 30 DAG. Houve maior retenção do herbicida imazapyr+imazapic na profundidade de $0-0.3 \mathrm{~m}$ na condição de $70 \% \mathrm{CC}$ e lixiviação para a profundidade de $0,3-0,6 \mathrm{~m}$ na condição de $130 \%$ CC, com redução no acúmulo de massa das plantas de melancia. O herbicida tem potencial carryover para a cultura do milho em solos mantidos a $70 \% \mathrm{CC}$.
\end{abstract}

Palavras-chave: Cultivo em sucessão. Imidazolinonas. Persistência. Residual.

\footnotetext{
${ }^{*}$ Corresponding author

${ }^{1}$ Received for publication in $01 / 06 / 2019$; accepted in $03 / 25 / 2020$.

Paper extracted from the master dissertation of the first author.

${ }^{2}$ Department of Plant Science, Universidade Federal Rural do Rio de Janeiro, Seropédica, RJ, Brazil; amanda.engagronoma@gmail.com ORCID: 0000-0002-8371-867X, jessica-agroleal@hotmail.com - ORCID: 0000-0001-6654-7998, langaro.ac@gmail.com - ORCID: 00000002-6746-5692, gs.decarvalho@gmail.com - ORCID: 0000-0001-6275-2345, camilafepi@hotmail.com - ORCID: 0000-0003-2861-2212.
} 


\section{INTRODUCTION}

The intensive agricultural production system in Brazil aims to achieve greater yield and profit, and a common practice in agricultural crops is the repeated succession of soybeans (Glycine max) corn (Zea mays) (PETTER et al., 2016; LÓPEZOVEJERO et al., 2016). In this scenario, the growing demand in the soybean-corn production model increases the importance of great technological advances and correct weed management, since they can cause significant losses in productivity (REZENDE et al., 2012).

The main form of weed control is chemical management, through the use of herbicides that can be applied in pre or post-emergence of weeds. The use of pre-emergent herbicides with a long residual effect is what gives production systems excellent assistance in weed control during the critical period of crop competition (ESQUIVEL; GONZÁLEZ; LEOR, 2010; MANCUSO; NEGRISOLI; PERIM, 2011). However, herbicides with residual action greater than the cultivation interval may cause negative effects on crops in succession, due to the presence of residues with biological activity that remain in the soil at concentrations sufficient to promote injuries, this phenomenon is called carryover (WALSH; DEFELICE; SIMS, 1993).

The residual effect of the herbicide is directly linked to its dynamics in the soil. When the herbicide reaches the soil, a series of redistribution and degradation processes begin, which regulate its fate in the environment and affect its persistence and effectiveness. These processes are known as interception or retention, degradation, transport and transformation, and eventually dissipation into the environment (ALLETTO et al., 2010). The main form of transport of a herbicide in the environment is leaching, which corresponds to the vertical movement of the molecule in the soil profile and is dependent on the characteristics of the herbicide and external factors, such as the physico-chemical properties of the soil, humidity and temperature conditions (MENDES et al., 2014).

The downward movement of the herbicide molecule can increase in soils with a high moisture content. The availability of water in the soil has great importance in the efficiency of the herbicide, because in addition to influencing microbial activity and the absorption of molecules by plants, it also influences the behavior of molecules at the interface of soil components (CARVALHO et al., 2012). Soils with moisture content below $60 \%$ of the field capacity reflect less phytotoxicity of the herbicides diclosulam and imazaquin for corn and sunflower plants, showing the effect of soil moisture on the behavior of these molecules (MONQUERO; MUNHOZ; HIRATA, 2013).
Among the herbicides that can be used in preemergence of soybean crops, there is the commercial mixture of the herbicides imazapyr + imazapic which belongs to the chemical group of imidazolinones. These herbicides act by inhibiting the enzyme acetolactate synthase (ALS - 2.2.1.6) present in chloroplasts, which is essential in the synthesis of the branched chain amino acids valine, leucine and isoleucine (ZULET et al., 2014).

The herbicide imazapyr [2- (4-isopropyl-4methyl-5-oxo-2-imidazolin-2-yl) nicotinic acid] and its metabolites have very low partition $(\mathrm{Kd})$ values, which demonstrates the potential for vertical movement, facilitated by solubility in water 11.272 ppm $\left(25^{\circ} \mathrm{C}\right)$, acid ionization constant $(\mathrm{pKa})$ of 1.9 and 3.6 and octanol / water (Kow) coefficient of 1.3 (RODRIGUES; ALMEIDA, 2011). The imazapir herbicide, as well as the other imidazolinones, is considered persistent in soil, with a half-life ranging from 25 to 142 days (SENSEMAN, 2007). Imazapic [(RS) -2- (4-isopropyl-4-methyl-5-oxo-2-imidazolin2-yl) -5-methylnicotinic acid] has water solubility of $2200 \mathrm{ppm}\left(25^{\circ} \mathrm{C}\right)$, ionization constant (pKa) 3.9 and octanol-water coefficient (Kow) 0.16 (SENSEMAN, 2007). The half-life in the soil is greater than 138 days $\left(25^{\circ} \mathrm{C}\right)$, varying from local edaphoclimatic conditions (SU et al., 2019).

Herbicides of the chemical group imidazolinones, are applied at very low rates in the soil, however they are still an environmental concern due to their anionic character, being very mobile in the soil and easily leached into groundwater (PORFIRI et al., 2015). The objective of the work was to evaluate the influence of water availability in the soil, on the leaching and residue of the commercial mixture imazapyr + imazapic for corn sown in succession to soybean.

\section{MATERIALS AND METHODS}

The experiment was carried in a greenhouse at the Federal Rural University of Rio de Janeiro, from October 2016 to April 2017. According to the Köppen climate classification, the region's climate is classified as Aw, with concentrated rain between November and March, average annual rainfall of $1,213 \mathrm{~mm}$ and average annual temperature of $23.9^{\circ} \mathrm{C}$ (CARVALHO et al., 2011).

Leaching columns, made of polyvinyl chloride (PVC), $0.60 \mathrm{~m}$ long and $0.25 \mathrm{~m}$ in diameter were used. The leaching columns were filled with soil, classified as Haplic Planosol, with no history of herbicide applications, previously passed through a 5 $\mathrm{mm}$ mesh sieve, whose analyzed physico-chemical characteristics are shown in (Table 1). 
Table 1. Physical-chemical characteristics of the soil.

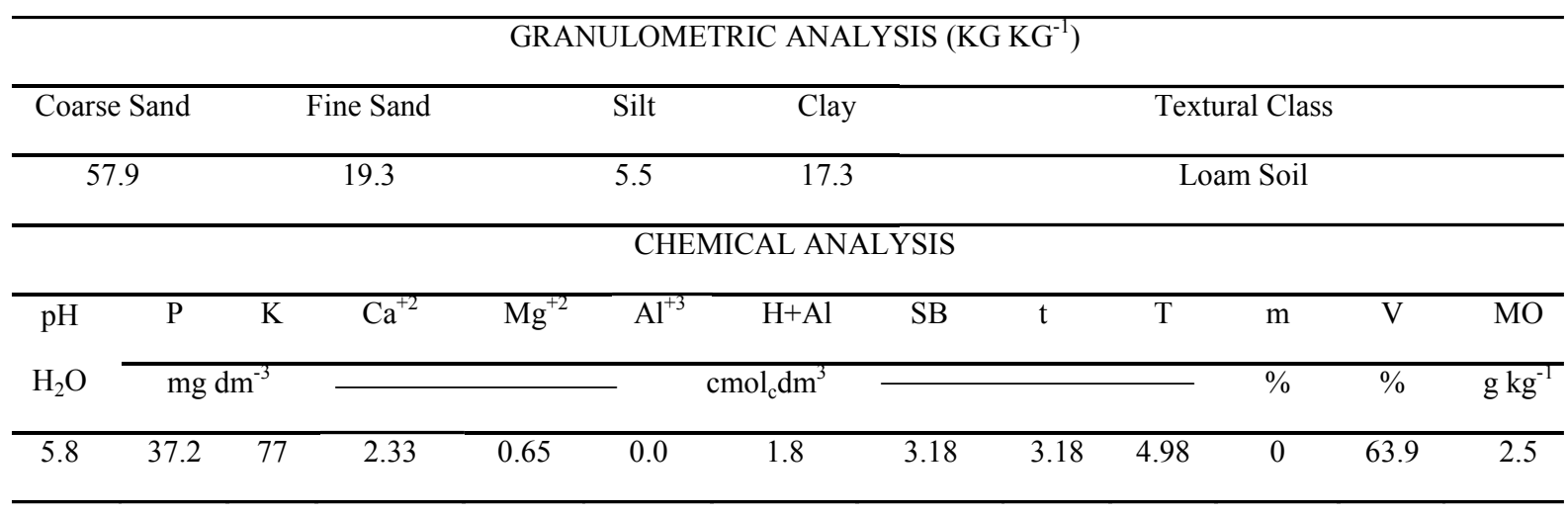

Analysis carried out at the Laboratory of Soil Analysis, Plant Tissue and Fertilizers of the Department of Soils at the University of Viçosa; pH-Potential Hydrogenion; P- Phosphorus; K- Potassium; $\mathrm{Ca}^{+2}$-Calcium; $\mathrm{Mg}^{+2}-\mathrm{Magnesium}$; $\mathrm{Al}^{+3}$ - Aluminum; H+Al- Potential Acidity; SB- Sum of base; t- Effective Cation Exchange Capacity; T-Cation exchange capacity at $\mathrm{pH}$ 7.0; m- Aluminum saturation index; V- Saturation Index by Bases; MO- Organic matter.

Before filling the columns, soil liming was performed with $750 \mathrm{~g} \mathrm{~m}^{3}$ of dolomitic limestone with $85 \%$ PRNT and fertilization with $35 \mathrm{~g} \mathrm{~m}^{3}$ of $\mathrm{P}_{2} \mathrm{PO}_{5}$ and $60 \quad \mathrm{~K}_{2} \mathrm{O}$. The columns remained inside a greenhouse, arranged vertically where in their basal part were placed screens in order to retain the soil and packed inside $20 \mathrm{~L}$ polyethylene pots filled with gravel to avoid water accumulation inside the columns.

The experiment was carried out in a $3 \times 3 \times 2$ factorial scheme, where factor A was irrigation (field capacity (CC), $70 \%$ of field capacity and $30 \%$ above field capacity $(130 \%)$, factor B the doses of the commercial mixture of herbicides imazapyr + imazapic (control (without herbicide), 52.5+17.5 (recommended dose) and 105+35 (double the recommended dose $\left.\mathrm{g} \mathrm{ha}^{-1}\right)$ and factor $\mathrm{C}$ soil depth $(0$ $0.3 \mathrm{~m}$ and $0.3-0.6 \mathrm{~m}$ ). A randomized block design with 4 replications totaling 36 experimental units.

The soil field capacity was determined from the soil water retention curve by the Richard's pressure chamber method, using pressures of $-6 ;-10$; $-30 ;-60 ;-100$ and $-1,500 \mathrm{kPa}$. The model used was based on the Van Genuchten equation (1980) (equation 1):

$$
\theta=\theta r+\theta s \frac{\theta s}{\left[1+(\alpha \cdot \varphi m)^{n}\right]} m
$$

being:

$\theta$ - soil water content $\left(\mathrm{kg} \mathrm{kg}^{-1}\right)$;

$\theta \mathrm{r}$ - residual water content $\left(\mathrm{kg} \mathrm{kg}^{-1}\right)$;

$\theta \mathrm{s}$ - water content at saturation $\left(\mathrm{kg} \mathrm{kg}^{-1}\right)$;

$\psi \mathrm{m}$ - matrix potential $(\mathrm{kPa})$;

$\alpha, \mathrm{n}$ and $\mathrm{m}$ - empirical parameters of the model.

For the values obtained in Richards' chamber, the best fit (equation 2) was obtained in the Soil Water Retentions Curve (SWRC), version 3.00 Beta (DOURADO NETO et al., 2001):

$\theta=0.0310+\frac{0.624}{\left[1+(2.3554 . \varphi m)^{3.0676}\right]} 0.1907$

The program used provided the following parameters: $\theta\left(\mathrm{kg} \mathrm{kg}^{-1}\right) ; \psi \mathrm{m}(\mathrm{kPa}) ; \theta \mathrm{r}=0.031 \mathrm{~kg} \mathrm{~kg}^{-1}$; $\theta \mathrm{s}=0.624 \mathrm{~kg} \mathrm{~kg}^{-1} ; \alpha=2.3554 ; \mathrm{m}=0.1907$; and $\mathrm{n}=$ 3.0676. The values of $\theta \mathrm{r}$ and $\theta \mathrm{s}$ indicate residual moisture and moisture at saturation, respectively. The data for $\alpha, \mathrm{m}$ and $\mathrm{n}$ are empirical parameters estimated by adjusting the data. The equation presented a coefficient of determination $\left(\mathrm{R}^{2}\right)$ of 0.965 , with a $5 \%$ significance level, indicating an adequate correspondence between the values obtained and those estimated by the adjustment. With the use of tensiometers, daily measurements of the soil water tension were performed, in order to maintain the soil with the pre-determined moisture in each treatment.

The soybean seed cv BRS 397, BRZ 11-6426 was sown at the top of the columns and then the herbicide application. The commercial mixture of imazapyr + imazapic was applied on the surface of the columns, in pre-emergence of the crop, sprayed using a $\mathrm{CO}_{2}$-pressurized backpack sprayer equipped with four flat-fan nozzles (XR110015, TeeJet Technologies), which delivered $150 \mathrm{~L} \mathrm{ha}^{-1}$ of spray solution at 45 psi. At the time of application, the climatic conditions were: temperature of $27{ }^{\circ} \mathrm{C}$, relative humidity of $75 \%$ and wind speed of $3.1 \mathrm{~km} \mathrm{~h}^{-1}$.

At 120 days after soybean emergence, the plants were collected and then the columns were 
separated by longitudinal section, giving rise to two sections, totaling 8 sections per treatment. The soil inside the section was divided with a plastic sheet separating them into two sections, the depths being 0 $-0.3 \mathrm{~m}$ and $0.3-0.6 \mathrm{~m}$.

Hybrid corn (Zea mays) 2B610PW (3 plants of 0-0.3 m and 3 plants of 0.3-0.6 m) was sown in half of each treatment (04 sections) and watermelon cv Congo (Citrullus lanatus) in the other half as a bioindicator species ( 4 plants of $0-0.3 \mathrm{~m}$ and 4 plants of $0.3-0.6 \mathrm{~m})$. For the choice of watermelon $\mathrm{cv}$ Congo as a bioindicator plant, preliminary tests were carried out (data not shown), which demonstrated the sensitivity of this species to sub-doses of the commercial mixture of the herbicides imazapyr + imazapic. After sowing the plants in the section, irrigation was carried out daily and the same amount of water from $0-0.3 \mathrm{~m}$ and $0.3-0.6 \mathrm{~m}$ was added to all section.

The response variables analyzed for corn and watermelon plants were: chlorophyll $a$ fluorescence at 15 and 30 days after germination (DAG) and shoot dry matter (MSPA) of plants at $30 \mathrm{DAG}$.

Chlorophyll $a$ fluorescence transient was measured using a portable fluorometer (Handy PEA, Hansatech, King's Lynn, Norkfolk, UK). The clips used for these measurements were placed in the middle third of fully expanded young leaves, in the morning, and the measurements were made 20 minutes after the leaves were adapted to the dark, using 08 repetitions per treatment ( 02 evaluations per experimental unit). Fluorescence emission was induced in an area of $4 \mathrm{~mm}$ leaf diameter by exposure of the sample to a pulse of saturating light at an intensity of $3,000 \mu \mathrm{mol} \mathrm{m} \mathrm{m}^{-2} \mathrm{~s}^{-1}$. From the transient fluorescence emission curve obtained after the pulse, the intensities determined at $50 \mu \mathrm{s}$ (initial fluorescence - $\left.\mathrm{F}_{0}\right), 100,300 \mu \mathrm{s}, 2\left(\mathrm{~F}_{\mathrm{J}}\right)$ and $30\left(\mathrm{~F}_{\mathrm{I}}\right) \mathrm{ms}$ and $\mathrm{F}_{\mathrm{M}}$ (maximum fluorescence) were used to calculate the established parameters by JIP Test (STRASSER; STRASSER, 1995; STRASSER; TSIMILLI-MICHAEL; SRIVASTAVA， 2004; TSSIMILLI-MICHAEL; STRASSER, 2008).

At the time of collection, the aerial part of the plants was collected and packed in paper bags and transported to the laboratory, where they were placed in a forced air circulation oven (temperature of $50 \pm$ $5^{\circ} \mathrm{C}$ ) until they reached a constant mass, and then the dry matter of the aerial part was determined using a precision balance.
The data were submitted to analysis of variance $(p \leq 0.05)$ and when indicate statistical significance, the mean irrigation and herbicide doses were compared by the Tukey test and soil depth (0$0.3 \mathrm{~m}$ and $0.3-0.6 \mathrm{~m}$ ) compared by the $t$ test at $5 \%$ of probability.

\section{RESULTS AND DISCUSSION}

\section{Assessment of Leaching Using Indicator Plant}

The injury caused to bioindicator plants was not intensified with the increase in herbicide dose (Figure 1). When analyzed, 15 days after germination (DAG), the fluorescence parameters showed interaction between the factors dose, water availability and depth (0-0.3 and 0.3-0.6 m). For plants at a depth of $0-0.3 \mathrm{~m}$ of the section under the herbicide residue, an increase in the parameter related to the photosynthetic performance index $\left(\mathrm{PI}_{\text {TOTAL }}\right)$ was observed, when compared to control treatment; the same was not observed for plants of $0.3-0.6 \mathrm{~m}$ of the section, and in the treatments $\mathrm{CC}$ and $70 \%$ of $\mathrm{CC}$, with the increase of the dose there was a reduction of the parameter. For parameter $\mathrm{DI}_{0} /$ $\mathrm{RC}$, related to energy loss in the form of heat, in 0 $0.3 \mathrm{~m}$, a reduction was observed under the residual herbicide only for the $130 \%$ treatment. For plants with a depth of 0.3-0.6 $\mathrm{m}$ in the section, there was a greater loss of energy, mainly in $\mathrm{CC}$ treatments and $70 \%$ when compared to treatment without herbicide. The ABS/RC parameter, in plants at a depth of $0-0.3$ $\mathrm{m}$, under the residual herbicide showed reduction, while the $\mathrm{ET}_{0} / \mathrm{RC}$ did not present significant alterations. For the depth of $0.3-0.6 \mathrm{~m}$, the ABS/RC parameter, the $130 \%$ treatment, showed a reduction under the residual herbicide, the $\mathrm{ET}_{0} / \mathrm{RC}$ parameter, did not present significant alterations.

At 30 DAG (Figure 2), there was an interaction between herbicide dose and plant depth. $\mathrm{PI}_{\mathrm{TOTAL}}, \mathrm{ABS} / \mathrm{RC}$ and $\mathrm{ET}_{0} \mathrm{RC}$ parameters did not change, remaining very close to the treatment in the absence of the herbicide. Lower values of the parameters were observed in comparison to $15 \mathrm{DAG}$, indicating a decrease in plant metabolism, and these were not able to metabolize the herbicide. This fact is proven since, there is a great loss of energy in the plant in the form of heat, as a way of escape from the plants to the effects caused by herbicides. 

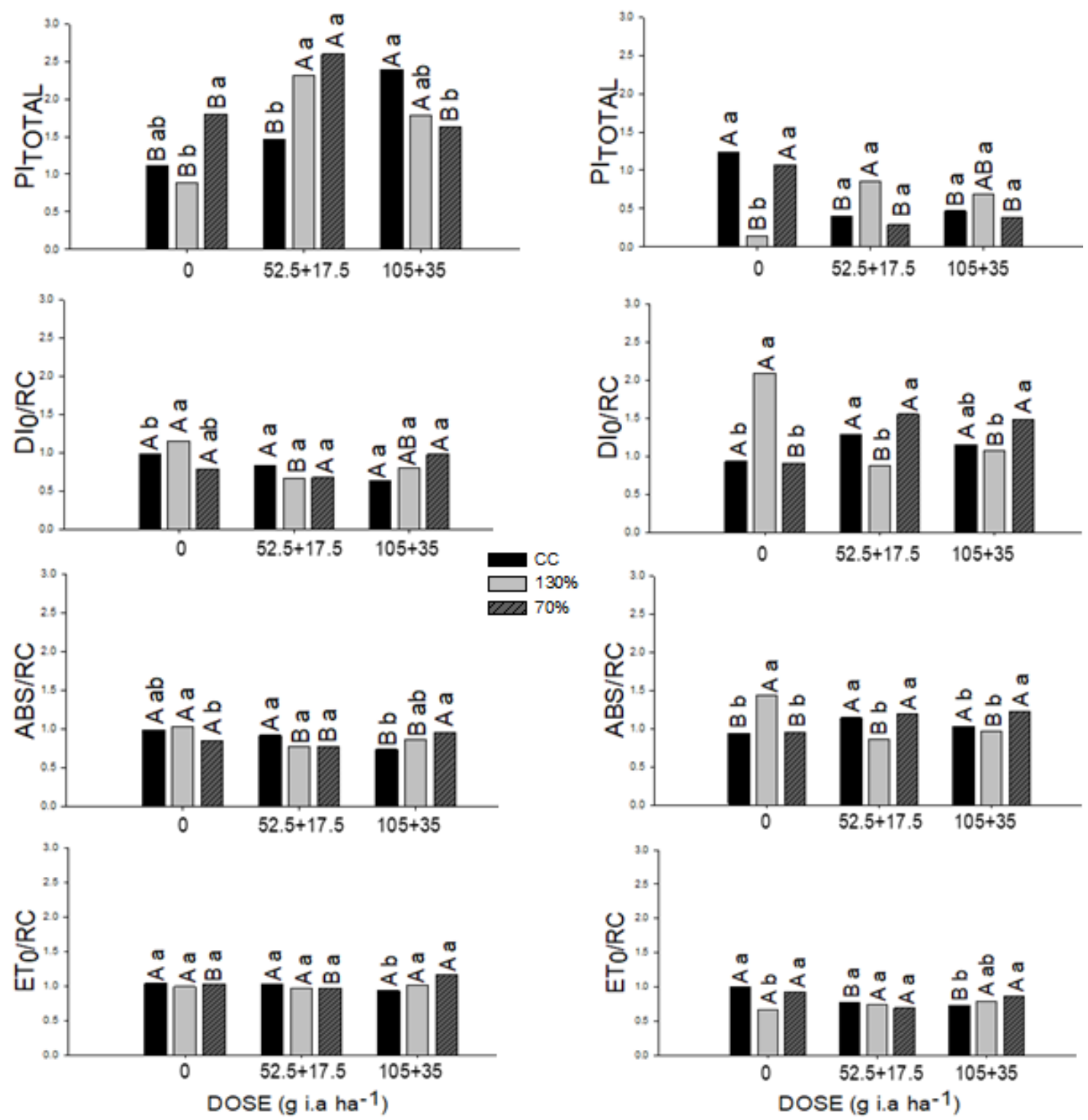

Figure 1. Chlorophyll $a$ fluorescence transient parameters, by the JIP test: $\mathrm{PI}_{\mathrm{TOTAL}}$ (total photosynthetic performance index), $\mathrm{DI}_{0} / \mathrm{RC}$ (total dissipation ratio of excitation energy not captured by the total reaction center), $\mathrm{ABS} / \mathrm{RC}$ (absorption flux per reaction center), $\mathrm{ET}_{0} / \mathrm{RC}$ (Reoxidation of plastoquinone via electron transport of an active reaction center), for watermelon plants 15 days after sowing at a depth of 0-0.3 m (left) and 0.3- $0.6 \mathrm{~m}$ (right), under doses of commercial mixture of imazapyr + imazapic herbicides and availability of water in the soil, where 0 - treatment without herbicide, 52.5 $+17.5\left(\mathrm{~g} \mathrm{ha}^{-1}\right)$-commercial dose; $105+35\left(\mathrm{~g} \mathrm{ha}^{-1}\right)$ - double the commercial dose, CC - single field capacity, $130 \%$ - soil with $30 \%$ above CC and $70 \%$ - soil 30\% below CC. Upper and lowercase letters equal for dose and depth of soil, respectively, do not differ by Tukey test, at $5 \%$ probability, for each variable analyzed. 

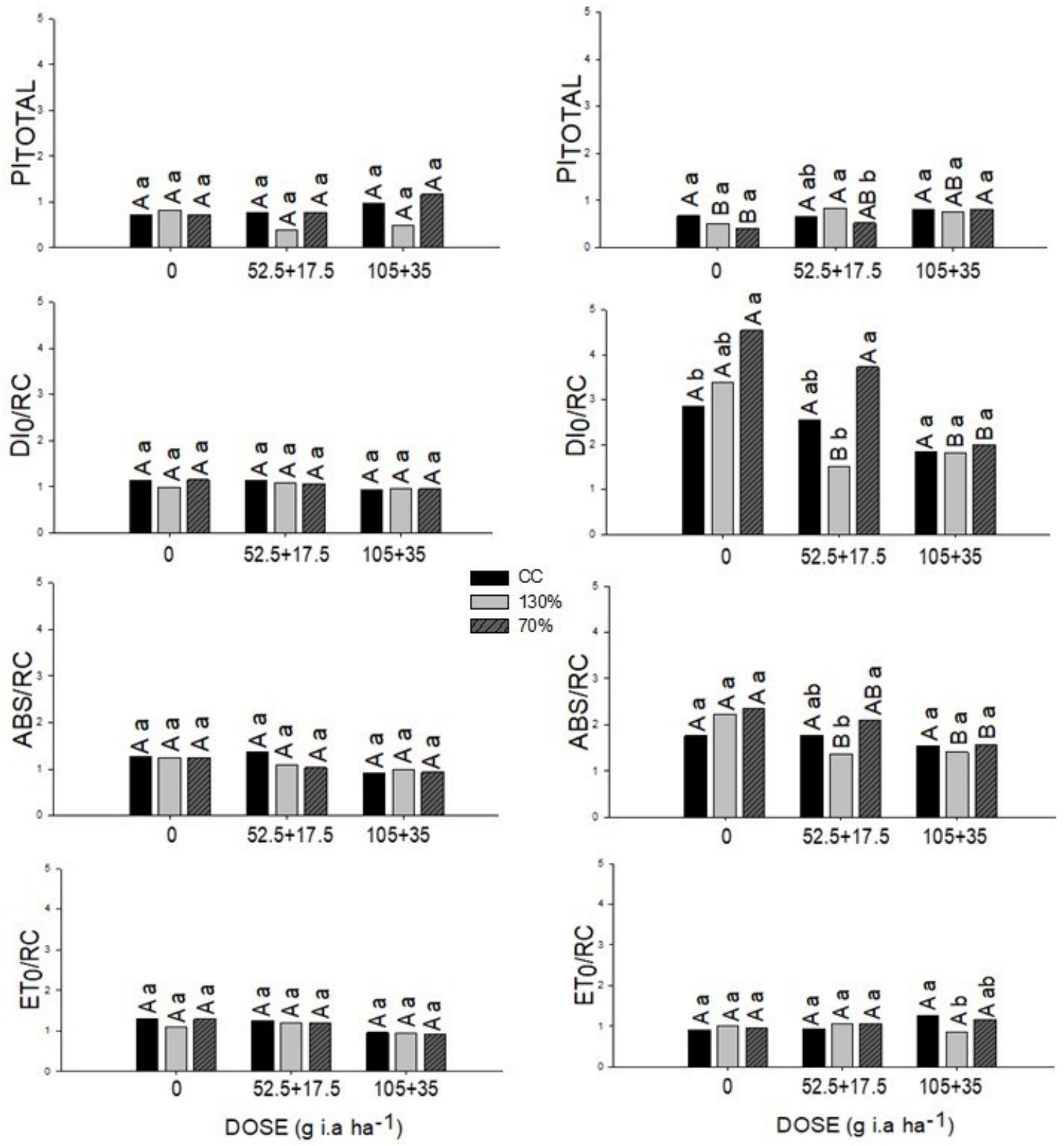

Figure 2. Chlorophyll $a$ fluorescence transient parameters, by the JIP test: $\mathrm{PI}_{\mathrm{TOTAL}}$ (total photosynthetic performance index), $\mathrm{DI}_{0} / \mathrm{RC}$ (total dissipation ratio of excitation energy not captured by the total reaction center), $\mathrm{ABS} / \mathrm{RC}$ (absorption flux per reaction center), $\mathrm{ET}_{0} / \mathrm{RC}$ (Reoxidation of plastoquinone via electron transport of an active reaction center), for watermelon plants 30 days after half depth of 0-0.3 m (left) and 0.3-0.6 m (right), under doses of commercial mixture of imazapyr + imazapic herbicides and availability of water in the soil, where 0 - treatment without herbicide, $52.5+17.5$ $\left(\mathrm{g} \mathrm{ha}^{-1}\right) ; 105+35\left(\mathrm{~g} \mathrm{ha}^{-1}\right), \mathrm{CC}$ - soil with field capacity, $130 \%$ - soil with $30 \%$ above CC and $70 \%$ - soil $30 \%$ below CC. Upper and lowercase letters equal for dose and depth of soil, respectively, do not differ by Tukey test, at $5 \%$ probability, for each variable analyzed.

Inhibition of the ALS enzyme caused by the residue of the herbicide imazapyr + imazapic reduced the photosynthetic rates of the plants; it may have occurred as a result of stomatal closure, reductions in $\mathrm{CO}_{2}$ absorption, as well as by the reduction of electron transport processes in thylakoid membranes (BALABANOVA et al., 2016). ALSinhibiting herbicides significantly increase starch and sucrose content in the leaves, which are transported at high rates to the roots, but long-distance transport is impaired and there is a decrease in transport by phloem, as the increase in starch content and sugars are higher than the plant can carry and assimilate (ZABALZA et al., 2004). The decrease in the transport of these sugars causes the accumulation of carbohydrates in the leaves, result to stomatal closure and thereby reducing photosynthesis, a fact observed in this study. In addition, there was an increase in the emission of energy in the form of heat in plants under residual herbicides, which indicates 
an interruption of the flow of electrons in the photochemical step of photosynthesis due to problems in plant metabolism.

There was an interaction between the factors of dose, availability of water in the soil and depth for the other biometric variables analyzed. The plant used as a bioindicator was sensitive to the residual herbicide in the soil, showing symptoms characteristic of ALS-inhibiting herbicides, such as reduced growth and leaf chlorosis (RIBEIRO et al., 2019). Herbicides from the chemical group of imidazolinones act at the substrate binding site that regulate the production of essential amino acids, thus causing negative effects on protein synthesis, inhibiting mitosis and reducing the translocation of sugars to the plant's demand regions (VIDAL et al., 2014).

The different levels of soil moisture favored the leaching or retention of the herbicide (Table 2), since plants at the depth of $0-0.3 \mathrm{~m}$ of the section, in the lowest availability of water suffered greater injury, showing the retention of the herbicide on the surface of drier soils. In cases where there was greater availability of water, with $130 \%$ of CC, plants at the depth of $0.3-0.6 \mathrm{~m}$ from the section showed greater damage to the presence of the herbicide, thus evidencing the leaching of the molecule to the deeper layers of the soil. The herbicides imazapyr and imazapic present solubility in water of $11.272 \mathrm{ppm}$ and $2200 \mathrm{ppm}$ (SENSEMAN, 2007), respectively, which associated with the high availability of water in the soil favor the leaching process of the molecules.

For the MSPA variable, plants at a depth of 0 $0.3 \mathrm{~m}$ (Table 2), associated with less water availability in the soil and in the condition of $\mathrm{CC}$, showed a reduction greater than $60 \%$ and $45 \%$ of this variable, respectively, when compared to the control. In the greater availability of water, there was no reduction in MSPA, due to the leaching of herbicides in the soil profile. Plants at a depth of 0.3 $0.6 \mathrm{~m}$ showed a reduction in dry matter accumulation in the presence of the herbicide, which was more severe in the greater availability of water, characterizing the leaching potential of the molecules to lower layers of the soil in the greater availability of water.

Table 2. Dry matter of the aerial part of watermelon plants sown in succession to soybean as a function on the doses of the commercial mixture of the herbicides imazapyr + imazapic and availability of water in the soil.

\begin{tabular}{|c|c|c|c|c|c|c|}
\hline \multicolumn{7}{|c|}{ DRY MATTER OF THE AERIAL PART } \\
\hline \multirow{2}{*}{$\begin{array}{c}\text { DOSE } \\
\left(\mathrm{g} \mathrm{a.i} \mathrm{ha}^{-1}\right)\end{array}$} & \multicolumn{3}{|c|}{$0-0.3 \mathrm{~m}(\mathrm{~g})$} & \multicolumn{3}{|c|}{$0.3-0.6 \mathrm{~m}(\mathrm{~g})$} \\
\hline & $130 \%$ & $\mathrm{CC}$ & $70 \%$ & $130 \%$ & $\mathrm{CC}$ & $70 \%$ \\
\hline 0 & $1.26 \mathrm{Ab}$ & $1.35 \mathrm{Ab}$ & $2.29 \mathrm{Aa}$ & $1.39 \mathrm{Aa}$ & $1.67 \mathrm{ABa}$ & $1.49 \mathrm{ABa}^{*}$ \\
\hline $52.5+17.5$ & $1.56 \mathrm{Aa}$ & $1.04 \mathrm{ABb}$ & $0.82 \mathrm{Bb}$ & $0.66 \mathrm{Bb}^{*}$ & $1.29 \mathrm{Ba}$ & $1.19 \mathrm{Ba}^{*}$ \\
\hline $105+35$ & $1.15 \mathrm{Aa}$ & $0.74 \mathrm{Ba}$ & $0.17 \mathrm{Cb}$ & $0.72 \mathrm{Bb}^{*}$ & $1.80 \mathrm{Aa}^{*}$ & $1.73 \mathrm{Aa}^{*}$ \\
\hline \multicolumn{7}{|c|}{ CV (\%) 20.78} \\
\hline
\end{tabular}

The averages followed by the same uppercase letters in a column and lowercase letters in the lines do not differ significantly by the Tukey test at $5 \%$ probability when comparing dose and water availability; the averages followed by $*$ are not differentiated by the $t$-test that compares the depth to $5 \%$ probability.

The leaching of herbicides from the chemical group of imidazolinones is also influenced by $\mathrm{pH}$, since herbicide sorption to soil colloids decreases with increasing soil $\mathrm{pH}$ value. The soil used in this study has a $\mathrm{pH}$ of 5.8, which favors the presence of molecules in the ionized form, since the herbicide imazapyr has pka of 3.6 and imazapic of 3.9. The higher the $\mathrm{pH}$ value of the soil in relation to the herbicide pka, the more available the molecule will be in the soil solution, thus favoring the herbicide leaching process when there is greater water availability (SHANER; HORNFORD, 2005).

\section{Carryover in Corn Crop}

For chlorophyll $a$ fluorescence parameters, at 15 days after germination (Figure 3), a small change in the total photosynthetic performance index $\left(\mathrm{PI}_{\text {TOTAL }}\right)$ was observed. Plants under $105+35 \mathrm{~g}$ a.i ha ${ }^{-1}$ herbicide dose, at a depth of 0-0.3 m, showed an increase in the parameter in treatments $130 \%$ and $70 \%$; for $0.3-0.6 \mathrm{~m}$ depth, this increase was observed in $\mathrm{CC}$ and $70 \%$. For the other parameters, no severe damage was observed to the photosynthetic apparatus of the plants, both for the herbicide dose factor and for the soil water availability (Figure 3). At 30 days after germination (Figure 4), the $\mathrm{PI}_{\mathrm{TOTAL}}$ parameter, for plants at a depth of $0-0.3 \mathrm{~m}$ in the section, reduced the commercial dose when compared to the treatment without herbicide. For plants at a depth of 0.3-0.6 m, there was a reduction in $\mathrm{PI}_{\text {TOTAL }}$ in the commercial dose and increase in the parameter in the dose $105+35 \mathrm{~g}$ a.i ha ${ }^{-1}$, in CC, when compared to treatment without herbicide 
(Figure 4). The $\mathrm{DI}_{0} / \mathrm{RC}$ parameter, related to energy dissipation in the form of heat, for plants at a depth of 0.3-0.6 m, showed a small increase in the commercial dose and double the dose, in the treatment in CC (Figure 4), this being a reflection of the lowest photosynthetic rate presented by the base plants. The other parameters indicated that there was no severe damage to the photosynthetic apparatus.
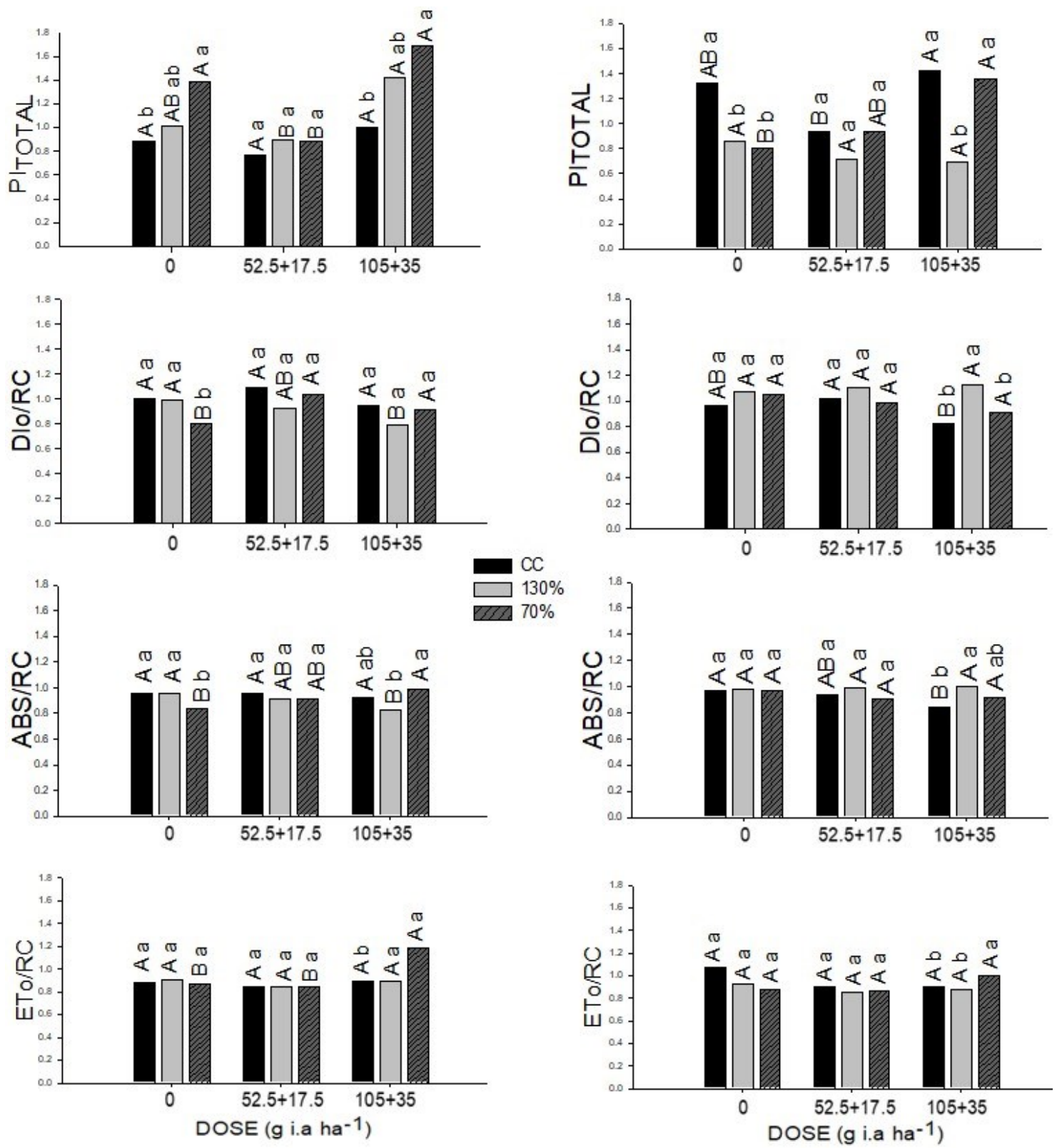

Figure 3. Chlorophyll $a$ fluorescence transient parameters, by the JIP test: $\mathrm{PI}_{\mathrm{TOTAL}}$ (total photosynthetic performance index), $\mathrm{DI}_{0} / \mathrm{RC}$ (total dissipation ratio of excitation energy not captured by the total reaction center), $\mathrm{ABS} / \mathrm{RC}$ (absorption flux per reaction center), $\mathrm{ET}_{0} / \mathrm{RC}$ (Reoxidation of plastoquinone via electron transport of an active reaction center), for corn plants 15 days after sowing at 0-0.3 m depth (left) and 0.3- $0.6 \mathrm{~m}$ (right), under the doses of the commercial mixture of the herbicides imazapyr + imazapic and availability of water in the soil, where 0 - treatment without herbicide, $52.5+17.5$ $\left(\mathrm{g} \mathrm{ha}^{-1}\right)$ - commercial dose; $105+35\left(\mathrm{~g} \mathrm{ha}^{-1}\right)$ - double the commercial dose, CC - soil at field capacity, $130 \%$ - soil with $30 \%$ above CC and 70\% - soil 30\% below CC. Upper and lowercase letters equal for dose and depth of soil, respectively, do not differ by Tukey test, at $5 \%$ probability, for each variable analyzed. 

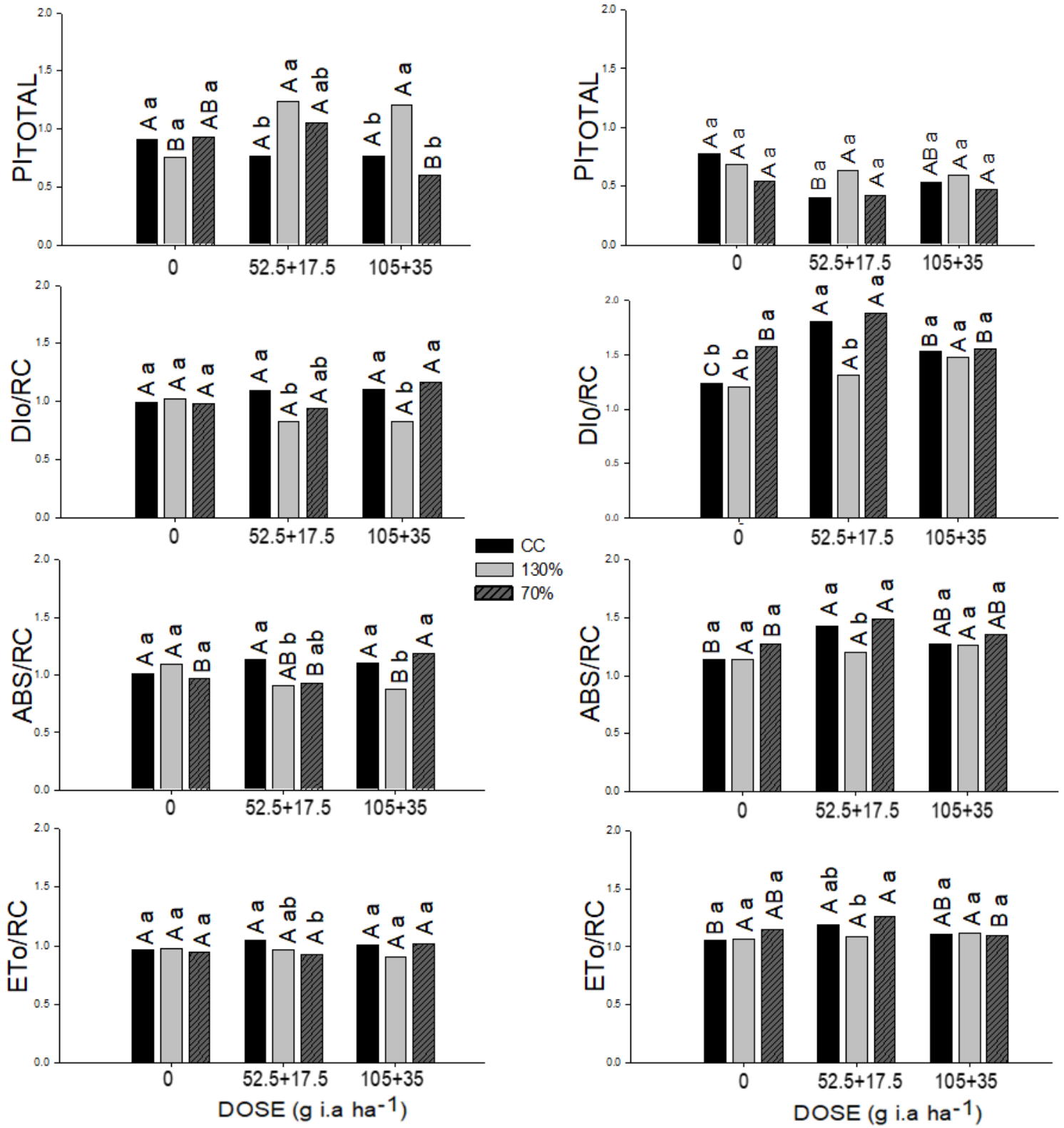

Figure 4. Chlorophyll $a$ fluorescence transient parameters, by the JIP test: $\mathrm{PI}_{\mathrm{TOTAL}}$ (total photosynthetic performance index), $\mathrm{DI}_{0} / \mathrm{RC}$ (total dissipation ratio of excitation energy not captured by the total reaction center), ABS/RC (absorption flux per reaction center), $\mathrm{ET}_{0} / \mathrm{RC}$ (Reoxidation of plastoquinone via electron transport of an active reaction center), for corn plants 30 days after sowing at a depth of 0-0.3 m (left) and 0.3-0.6 m (right), under the doses of the commercial mixture of the herbicides imazapyr + imazapic and availability of water in the soil, where 0 - treatment without herbicide, $52.5+17.5$ $\left(\mathrm{g} \mathrm{ha}^{-1}\right)$ - commercial dose; $105+35\left(\mathrm{~g} \mathrm{ha}^{-1}\right)$ - double the commercial dose, CC - soil at field capacity, $130 \%$ - soil with $30 \%$ above CC and 70\% - soil 30\% below CC. Upper and lowercase letters equal for dose and depth of soil, respectively, do not differ by Tukey test, at $5 \%$ probability, for each variable analyzed.

Chlorophyll $a$ fluorescence can be altered by a number of factors that are not directly linked to photosynthesis. Herbicides of the chemical group of imidazolinones, even though they do not act directly in photosynthetic processes, work by inhibiting cell growth and DNA synthesis, which are essential in protein metabolism and synthesis. DNA is the main constituent of mitochondria and chloroplasts, where photosynthesis occurs, responsible for producing energy through the synthesis of amino acids. In addition, pyruvate accumulation has the potential to activate fermentation processes and electron regulation for cytochrome and alternative respiratory pathways (ZABALZA et al., 2004; ZULET et al., 2014).

In the results obtained for corn crop, a significant interaction was observed between soil water availability, herbicide doses and the depth at which the plants were evaluated in all biometric variables at $30 \mathrm{DAG}$. The residual herbicide imazapyr + imazapic caused a reduction in the dry matter of the aerial part of the plants, when at a 
depth of $0-0.3 \mathrm{~m}$ in the lowest water availability and $\mathrm{CC}$; when at the depth of 0.3-0.6 m the reduction occurred in the highest water availability confirming the result obtained for commercial dose and double the dose, in the leaching assay.

At the lowest depth, the plants in the $\mathrm{CC}$ and $70 \%$ suffered a reduction in MSPA under the presence of the herbicides (Table 3). In $\mathrm{CC}$ the reduction was $46 \%$ and $44 \%$ and under the lowest water availability of $41 \%$ and $67 \%$, for the dose and double the dose of the herbicide, respectively. At the depth of 0.3-0.6 m, there was a reduction in MSPA in the highest water availability, which was $48 \%$ and $34 \%$, for dose and double dose, respectively, and relative to the control without herbicides. In the lower availability there was a reduction in the dry matter accumulation of the aerial part of the plants, confirming that the herbicide was retained on the soil surface.

Table 3. Dry matter of the aerial part of corn plants sown in succession to soybean as a function on the doses of the commercial mixture of the herbicides imazapyr + imazapic and availability of water in the soil (CC- field capacity, $130 \%$ above CC, $70 \%$ below CC ).

\begin{tabular}{|c|c|c|c|c|c|c|}
\hline \multicolumn{7}{|c|}{ DRY MATTER OF THE AERIAL PART } \\
\hline \multirow[b]{2}{*}{$\begin{array}{c}\text { DOSE } \\
\left(\mathrm{g} \mathrm{a.i} \mathrm{ha}^{-1}\right)\end{array}$} & \multicolumn{3}{|c|}{$0-0.3 \mathrm{~m}(\mathrm{~g})$} & \multicolumn{3}{|c|}{$0.3-0.6 \mathrm{~m}(\mathrm{~g})$} \\
\hline & $130 \%$ & $\mathrm{CC}$ & $70 \%$ & $130 \%$ & $\mathrm{CC}$ & $70 \%$ \\
\hline 0 & $6.68 \mathrm{Aa}$ & $6.35 \mathrm{Aa}$ & $6.17 \mathrm{Aa}$ & $5.59 \mathrm{Aa}$ & $5.72 \mathrm{Aa}$ & $6.21 \mathrm{Aa}$ \\
\hline $52.5+17.5$ & $6.95 \mathrm{Aa}$ & $3.49 \mathrm{Bb}$ & $3.63 \mathrm{Bb}$ & $2.93 \mathrm{Bb}^{*}$ & $5.19 \mathrm{Aa}^{*}$ & $5.86 \mathrm{Aa}^{*}$ \\
\hline $105+35$ & $6.21 \mathrm{Aa}$ & $3.60 \mathrm{Bb}$ & $2.06 \mathrm{Cc}$ & $3.69 \mathrm{Bb}$ & $2.53 \mathrm{Bb}$ & $5.93 \mathrm{Aa}^{*}$ \\
\hline \multicolumn{7}{|c|}{ CV (\%) 14.40} \\
\hline
\end{tabular}

The averages followed by the same uppercase letters in a column and lowercase letters in the lines do not differ significantly by the Tukey test at $5 \%$ probability when comparing dose and water availability; the averages followed by * are not differentiated by the $t$-test that compares the depth to $5 \%$ probability.

The persistence of herbicides in the chemical group of imidazolinones is highly influenced by soil attributes, with low sorption capacity in soils with low organic carbon content and clay (GUIMARÃES et al., 2016). Soils with a sandy texture and low organic carbon content as used in this work (Table 1), leave the molecules more available in the solution, increasing the availability for absorption by plants, which can cause losses in the quality and productivity of sensitive crops in succession, in addition to allowing leaching to deeper layers in conditions of greater water availability.

In previous studies evaluating the persistence of the herbicide imazethapyr according to climatic conditions, time and application rate in two seasons with different climatic conditions, using white mustard as a bioindicator plant, Radovanov (2017) found that persistence depends on the level of precipitation over time, with greater persistence in drier seasons. This dependence of precipitation was observed in this assay, with the herbicide remaining on the soil surface with low water availability, resulting in a higher chance of carryover for corn in succession. While, in the condition of higher moisture in the soil, the herbicide was leached to the lower layers, being removed from the area explored by the roots of the crop in succession, reducing the carryover. However, soil profile mobility is not positive when considering environmental issues, since the herbicide will be in soil areas with less microbial activity, which according to (LOUX;
LIEBL; SLIFE, 1989; BUNDT et al., 2014) is the main means of degradation of these herbicides, reaching the groundwater.

\section{CONCLUSIONS}

The commercial mixture of the herbicides imazapyr + imazapic has the potential for vertical mobility in the soil, which is influenced by water availability. The conditions of higher soil moisture favor the leaching of herbicides at depths greater than $0.3 \mathrm{~m}$, while in soil conditions with low humidity the herbicide remains retained at a depth of $0-0.3 \mathrm{~m}$. The commercial mixture of the herbicides imazapyr + imazapic has carryover potential for corn cultivation in soils maintained under water deficit, since the roots of the plants will be in the superficial layers of the soil. Under conditions of greater water availability, the mobility of the herbicide increases, reducing the carryover potential for maize crops.

\section{ACKNOWLEDGEMENTS}

This study was financed in part by the Coordenação de Aperfeiçoamento de Pessoal de Nível Superior- Brasil (CAPES), Finance Code 001, and by Fundação Carlos Chagas Filho de Amparo à Pesquisa do Estado do Rio de Janeiro (FAPERJ). 


\section{REFERENCES}

ALLETTO, L. et al. Tillage management effects on pesticide fate in soils. A review. Agronomy For Sustainable Development, 30: 367-400, 2010.

BALABANOVA, D. A et al. Photosynthetic Performance of the Imidazolinone Resistant Sunflower Exposed to Single and Combined Treatment by the Herbicide Imazamox and an Amino Acid Extract. Frontiers in Plant Science, 7: 1-10, 2016.

BUNDT, A. D. C. et al. Lixiviação de imidazolinonas em resposta a diferentes manejos de irrigação em solo de cultivo de arroz irrigado. Ciência Rural, 44: 1943-1949, 2014.

CARVALHO, D. F. et al. Coeficientes da equação de Angström-Prescott e sua influência na evapotranspiração de referência em Seropédica, RJ. Revista Brasileira de Engenharia Agrícola, 15: 108-116, 2011.

CARVALHO, S. J. P. et al. Atividade residual de seis herbicidas aplicados ao solo em época seca. Revista Ceres, 59: 278-285, 2012.

DOURADO NETO, D. et al. Programa para confecção da curva de retenção de água no solo, modelo Van Genuchten: Soil Water Retention Curve, SWRC. Version 3,00 beta. Piracicaba: USP, 2001.

ESQUIVEL, V. A. E.; GONZÁLEZ, X. R.; LEOR, E. N. B. Evaluación de herbicidas residuales para el control de malezas em Guanábana (Annona muricata L.). Revista Chapingo: Serie Horticultura, 16: 512,2010 .

GUIMARÃES, A. et al. Eficácia do imazapic no controle de capim-camalote aplicado em solos de diferentes texturas. Revista Brasileira de Herbicidas, 15: 213-220, 2016.

LÓPEZ-OVEJERO, R. F. et al. Interferência e controle de milho voluntário tolerante ao glifosato na cultura da soja. Pesquisa Agropecuária Brasileira, 51: 340-347, 2016.

LOUX, M. M.; LIEBL, R. A.; SLIFE, F. W. Adsorption of imazaquim and imazethapyr on soils, sediments and selected adsorbants. Weed Science, 37: 712-718, 1989.

MANCUSO, M. A. C.; NEGRISOLI, E.; PERIM, L. Efeito residual de herbicidas no solo ("Carryover"). Revista Brasileira de Herbicidas, 10: 151-164, 2011.
MENDES, K. F. et al. A proposal to standardize herbicide sorption coefficients in Brazilian tropical soils compared to temperate soils. Journal of Food, Agriculture \& Environment, 12: 424-433, 2014.

MONQUERO, P. A.; MUNHOZ, W. S.; HIRATA, A. C. S. Persistência de imazaquim e diclosulam em função da umidade do solo. Revista Agroambiente, 7: 331-337, 2013.

PETTER, F. et al. Sorção e dessorção de diuron em Latossolo sob a aplicação de biochar. Bragantia, 75: 487-496, 2016.

PORFIRI, C. et al. Adsorption and transport of imazapir through intact soil columns taken from two soils under two tillage systems. Geoderma, 251252: 1-9, 2015.

RADOVANOV, K. J. Imazethapyr persistence in sandy loam detected using white mustard bioassay. Journal of Environmental Science and Health, Part B Pesticides, Food Contaminants, and Agricultural Wastes, 52: 711-718, 2017.

REZENDE, B. P. M. et al. Efeito do fomesafen + fluazifop-p-butil associados com inseticidas no controle das plantas daninhas na cultura da soja. Revista Brasileira de Ciências Agrárias, 7: 608613, 2012.

RIBEIRO, S. R. S. et al. Watermelon sensitivity to residual of pre-emergent herbicide applied in soybean crop. Revista Brasileira de Herbicidas, 18: 1-6, 2019

RODRIGUES, B. N.; ALMEIDA, F. S. Guia de herbicidas. 6. ed. Londrina, PR: IAPAR, 2011. 764 p.

SENSEMAN, SCOTT A. Herbicide handbook. 9. ed. Lawrence, US: Weed Science Society of America, 2007. 458 p.

SHANER, D. L, HORNFORD, R. Soil interactions of imidazolinone herbicides used in Canada. In: VAN ACKER, R. C. (Ed.). Quebec, CA: Soil Residual Herbicides and Management Topics in Canadian Weed Science, 2005. v. 3, p. 23-30.

STRASSER, B. J.; STRASSER, R. J. Measuring fast fluorescence transients to address environmental question: the JIP test. In: MATHIS, P. (Eds.). Photosynthesis: from light to biosphere. Dordrecht, NI: Kluwer Academic Publisher, 1995. v. 5, p. $977-980$

STRASSER, R. J.; TSSIMILLI-MICHAEL, M.; SRIVASTAVA, A. Analysis of the Chlorophyll $a$ fluorescence transient. In: PAPAGEORGIOU, C.; 
GOVINDJEE, R. (Ed.). Chlorophyll Fluorescence: a signature of photosynthesis. Dordrecht, NI: Springer, 2004. v. 19, cap. 12, p. 321-362.

SU, W. et al. Adsorption and degradation of imazapic in soils under different environmental conditions. PLoS ONE, 14: 1-11, 2019.

TSSIMILLI-MICHAEL, M.; STRASSER, R. J. In vivo assessment of plants vitality: applications in detecting and evaluating the impact of Mycorrhization on host plants. In: VARMA, A. (Ed.), Mycorrhiza: state of the art, genetics and molecular biology, eco-function, biotechnology, ecophysiology, structure and systematics. Dordrecht, NI: Springer, 2008. v. 3, p. 679-703.

VAN GENUCHTEN, M. T. A closed form equation for predicting the hydraulic conductivity of unsaturated soils. Soil Science Society of America Journal, 44: 892-898, 1980.

VIDAL, R. A. et al. Mecanismos de ação dos herbicidas. In: Aspectos da biologia e manejo das plantas daninhas. São Carlos: RiMa Editora, 1: 235$255,2014$.

WALSH, J. D.; DEFELICE, M. S.; SIMS, B. D. Soybean (Glycine max) herbicide carryover to grain and fiber crops. Wedd Technology, 7: 625-632, 1993.

ZABALZA, A. et al. Carbohydrate Accumulation in Leaves of Plants Treated with the Herbicide Chlorsulfuron or Imazethapyr Is Due to a Decrease in Sink Strength. Journal Agricultural and Food Chemistry, 52: 7601-7606, 2004.

ZULET, A. et al. Fermentation and alternative oxidase contribute to the action of amino acid biosynthesis-inhibiting herbicides. Journal of Plant Physiology, 175: 102-112, 2014. 